\title{
Aktivitas Psikis Tokoh dalam Novel Pecinan Karya Ratna Indraswari Ibrahim
}

\author{
Febria Cindra Keswara ${ }^{1}$, Mardian ${ }^{2}$, Gunta Wirawan ${ }^{3}$ \\ STKIP Singkawang, Singkawang, Indonesia \\ riafebria95@gmail.com ${ }^{1}$, mardiandeeza@gmail.com ${ }^{2}$, gwirawan91@gmail.com ${ }^{3}$
}

\section{Keywords :}

Tokoh, Psikologi Sastra,

Aktivias Psikis

\begin{abstract}
Penelitian ini bertujuan untuk mengetahui aktivitas psikis yang terdapat dalam novel Pecinan.Tujuan khusus penelitian ini adalah untuk mendapatkan informasi sebagai berikut (1) Pendeskripsian gejala kognitif dalam novel Pecinan karya Ratna Indraswari Ibrahim; (2) Pendeskripsian gejala afektif tokoh dalam novel Pecinan karya Ratna Indraswari Ibrahim; (3) Pendeskripsian gejala konatif tokoh dalam novel Pecinan karya Ratna Indraswari Ibrahim; (4) Pendeskripsian Implementasi hasil penelitian Aktivitas Psikis Tokoh dalam Novel Pecinan karya Ratna Indraswari Ibrahim terhadap rencana pelaksanaan pembelajaran di sekolah. Metode dalam penelitian ini adalah metode deskriptif. Data dalam penelitian ini berupa kutipan-kutipan (kata, frasa, kalimat). Teknik pengumpulan data menggunakan teknik studi dokumenter dengan peneliti sebagai instrumen utama. Langkah kerja yang dilakukan peneliti antara lain, membaca novel Pecinan, mengklasifikasikan data sesuai dengan masalah yang diteliti, menginterpretasikan data yang ada, menganalisis pengimplementasian perencanaan pembelajaran,
\end{abstract} mendiskusikan hasil penelitian, menyimpulkan hasil penelitian. Berdasarkan hasil analisis terhadap novel Pecinan karya Ratna Indraswari Ibrahim, maka dapat disimpulkan (1) terdapat 62 kutipan yang berhubungan dengan gejala kognitif dalam novel Pecinan, hal yang mendasarinya adalah perhatian, pengamatan, tanggapan, fantasi, ingatan, pikiran, intuisi; (2) terdapat 19 kutipan yang berhubungan dengan gejala afektif dalam novel Pecinan, hal yang mendasarinya adalah perasaan, affek dan stemming, suasana hati, simpati dan empati; (3) terdapat 46 kutipan yang berhugejala konatif dalam novel Pecinan, hal yang mendasarinya adalah otomatisme, refleks, insting, kebiasaan, nafsu, keinginan, hasrat, kecendrungan; (4) masalah implementasi aktivitas psikis tokoh terhadap pembelajaran sastra Indonesia yaitu suatu penerapan yang mengajarkan siswa untuk menggunakan metode dan media pembelajaran yang menarik, dan sesuai dengan materi yang diajarkan. 


\section{INTRODUCTION}

Novel merupakan prosa yang panjang, mengandung rangkaian cerita kehidupan seseorang dengan orang-orang di sekelilingnya dengan menonjolkan watak dan sifat pelaku. Prosa fiksi (novel) dibangun oleh dua unsur yaitu unsur instrinsik dan unsur ekstrinsik. Peneliti memilih Novel Pecinan karena objek yang dikaji berhubungan dengan psikologi, terutama psikologi sastra. Pada dasarnya psikologi sastra dibangun atas dasar asumsi-asumsi genesis (dugaan awal), dalam kaitannya dengan asal-usul karya, artinya psikologi sastra dianalisis dalam kaitannya dengan aspek-aspek kejiwaan manusia yang begitu mendalam.Menurut Ratna, 2004: 344 untuk memahami psikologi sastra, ada tiga cara yang harus dilakukan, 1) melalui pemahaman teori-teori psikologi untuk kemudian dilakukan analisis terlebih dahulu terhadap suatu karya sastra, 2) dengan menentukan terlebih dahulu karya sastra yang akan dijadikan objek penelitian, kemudian tentukan teori-teori psikologi yang dianggap relevan untuk digunakan, 3) secara simultan menentukan teori dan objek penelitian.

Novel Pecinan karya Ratna Indraswari Ibrahim ini mengisahkan tentang bias gender antara laki-laki dan perempuan. Hal ini biasanya terjadi di kalangan masyarakat Tionghoa, di mana kedudukan kaum perempuan lebih rendah dibanding kaum laki-laki. Dalam diri setiap manusia, pasti melakukan aktivitas baik fisik maupun psikis. Aktivitas fisik yang dilakukan manusia akan sangat mudah untuk dilihat, tapi tidak dengan aktivitas psikis. Aktivitas psikis manusia dilakukan untuk mencapai tujuan tertentu yang diinginkan manusia yang dicerminkan dengan tingkah laku. Menurut Emir dan Saifur Rohman (2015: 164) kegiatan psikis pada umumnya digolongkan dalam empat kategori, yaitu (1) gejala kognitif yaitu aktivitas berpikir seseorang untuk memahami / mencari tahu kebenaran dari suatu hal, dan gejala ini meliputi perhatian, pengamatan, tanggapan, fantasi, ingatan, pikiran, dan intuisi. (2) gejala afektif yaitu kegiatan psikis yang berkenaan dengan perasaan dan emosi manusia, dan gejala ini meliputi perasaan, affek, dan stemming, suasana hati, simpati dan empati. (3) gejala konatif yaitu aktivitas psikis manusia yang mengandung usaha aktif dan berhubungan dengan pelaksanaan suatu tujuan yang menjadi titik akhir dari gerakan yang menuju suatu arah, meliputi dorongan yaitu dorongan pada tingkat biologis dan dorongan pada tingkat psikologis. Berdasarkan uraian di atas hal inilah yang membuat peneliti memilih aktivitas psikis dalam penelitiannya, karena begitu banyaknya aktivitas psikis manusia yang sangat menarik untuk dibahas satu- persatu.

Dalam kaitannya dengan pembelajaran Bahasa Indonesia di sekolah maka hubungan penelitian ini terdapat dalam (KTSP) Kurikulum Tingkat Satuan Pendidikan pada SMA kelas sebelas (XI) semester 1 dengan Standar Kompetensi (SK) Membaca : 7. Memahami berbagai hikayat, novel Indonesia/terjemahan. Kompetensi Dasar (KD) 7.2 Menganalisis unsur-unsur instrinsik dan unsur ekstrinsik novel Indonesia/terjemahan. Indikator dalam pembelajaran yaitu (1) mengidentifikasi unsurunsur instrinsik (tema, tokoh, penokohan, dan amanat) dalam novel Indonesia, (2) Menganalisis unsur intrinsik (tema, tokoh, penokohan, dan amanat) dalam novel Indonesia. Dari penjelasan di atas, peneliti ini akan menelaah tentang aktivitas psikis tokoh dalam novel Pecinan Karya Ratna Indraswari Ibrahim.

\section{METHOD}

Dalam penelitian ini metode yang digunakan adalah metode deskriptif. Moleong (2013: 11) menyatakan bahwa "Deskriptif artinya data yang dikumpulkan adalah berupa kata-kata, gambar, dan bukan angka-angka. Metode deskriptif dalam penelitian ini digunakan untuk memberikan gambaran dan memaparkan hasil tentang aktivitas psikis tokoh yang terkandung di dalam novel Pecinan karya Ratna Indraswari Ibrahim. Bentuk penelitian yang digunakan adalah bentuk kualitatif. Penelitian ini bertujuan untuk mendeskripsikan aktivitas psikis yang dialami tokoh dalam novel Pecinan karya Ratna Indraswari Ibrahim yang meliputi gejala kognitif, gejala afektif, dan gejala konatif. Pendekatan yang digunakan adalah pendekatan psikologi sastra. Pendekatan psikologi sastra berarti menganalisis tentang aktivitas psikis atau kejiwaan yang dialami oleh tokoh dalam novel Pecinan karya Ratna 
Indraswari Ibrahim. Untuk menganalisis kegiatan kejiwaan tersebut peneliti menggunakan hubungan stimulus-respon.

\section{RESULTS AND DISCUSSIONS}

Dalam hal ini yang diteliti peneliti adalah tentang gejala kognitif (perhatian, pengamatan, tanggapan, fantasi, ingatan, intuisi), gejala afektif (perasaan, affek dan stemming, suasana hati, simpati dan empati) dan gejala konatif ( dorongan dan kemauan).

\section{Gejala Kognitif}

Gejala kognitif ialah segenap gejala yang terdapat dalam kejiwaan sebagai hasil pengenalan.

a. Perhatian

Perhatian merupakan stadium persiapan sebelum sampai pada pengamatan. Memperhatikan berarti mengkonsentrasikan diri, mengarahkan aktivitas psikis pada satu titik sentral. Berdasarkan penjelasan di atas perhatian terdapat pada kutipan berikut ini.

\section{“Aku sedang sibuk menulis disertasi. Di sisi lain, aku ikut organisasi yang menangani kekerasan pada perempuan dan anak.}

(Ibrahim, 2011: 28).

Kutipan di atas menandakan adanya perhatian. Hal ini terlihat dengan Anggraini yang lebih fokus terhadap disertasi dan penanganan kasus kekerasan terhadap perempuan dan anak.

a. Pengamatan

Pengamatan adalah usaha manusia untuk mengenal dunia riil baik mengenai diri sendiri maupun dunia sekitarnya melalui panca indranya. Berdasarkan uraian di atas pengamatan yang berhubungan dengan pengamatan terdapat dalam kutipan berikut ini.

“Anggraini menikmati malam di kota Malang dengan berjalan-jalan sendirian saja. Lagilagi ia kecewa karena yang berdiri disepanjang Kayuta ngan da;jn Pecinan adalah deretan swalayan. Tidak ditemukannya lagi toko-toko di mana pembeli bisa ngobrol dengan pemiliknya. (Ibrahim, 2011: 31).

Kutipan di atas menandakan adanya gejala kognitif yang berhubungan dengan pengamatan. Hal ini terlihat dari Anggraini yang mengamati keadaan di sepanjang kawasan Kayutangan dan Pecinan. Di sepanjang jalan tersebut kini yang tampak hanyalah deretan swalayan, berbeda dengan dulu yang dipenuhi oleh toko-toko.

b. Tanggapan

Tanggapan merupakan bayangan ataau kesan yang tertinggal di dalam diri seseorang setelah kita melakukan pengamatan terhadap suatu objek.

Anggraini semakin kecewa karena Malang berwajah sama dengan semua kota metropolis mini yang angkuh. (Ibrahim, 2011: 30).

Kutipan di atas menandakan adanya gejala kognitif yang berhubungan dengan tanggapan. Hal ini terlihat dari Anggraini yang mengungkapkan rasa kecewanya terhadap keadaan kota Malang yang sekarang.

c. Fantasi

Fantasi adalah kemampuan jiwa untuk menggunakan tanggapan-tanggapan yang sudah ada untuk menciptakan tanggapan-tanggapan baru. Berdasarkan penjelasan di atas fantasi terdapat pada kutipan berikut ini.

“Anggraini mulai bermimpi tentang Bulan, yang kini tengah sekolah Ekonomi Manajemen, kelak bisa seperti Lely Kurniawati. (Ibrahim, 2011: 137).

Kutipan di atas menandakan adanya gejala kognitif yang berhubungan dengan fantasi. Hal ini terlihat dari Anggraini yang mempunyai mimpi kelak di suatu hari ia menginginkan anaknya bisa sukses seperti sahabat kecilnya dulu.

d. Ingatan

Ingatan adalah kemampuan untuk mencamkan, menyimpan dan memproduksi kesan-kesan. Berdasarkan penjelasan di atas ingatan terdapat pada kutipan berikut ini. 


\section{"Anggraini terlihat sedih. Entahlah. Belakangan ini, Anggraini memang suka mengenangkan sahabat-sahabat di masa kecil. (Ibrahim, 2011: 16)}

Kutipan di atas menandakan adanya gejala kognitif yang berhubungan dengan ingatan. Hal ini terlihat dari Anggraini yang kembali teringat dengan sahabat-sahabatnya di masa kecil.

e. Pikiran

Berpikir merupakan suatu aktivitas psikis yang intensional dan terjadi apabila seseorang menjumpai masalah yang harus dipecahkan. Berdasarkan penjelasan di atas pikiran terdapat dalam kutipan berikut ini.

Anggraini tergeragap dari lamunan, lalu kembali menyimak biografi Lely. Apa yang pernah diucapkan Lely itu membuat Anggraini berpikir bahwa sepertinya, Lely memang dibesarkan dalam suasana bias gender (Ibrahim, 2011: 11).

Kutipan di atas menandakan adanya gejala kognitif yang berhubungan dengan berpikir. Hal ini terlihat dari Anggraini yang berpikir kalau Lely memang dibesarkan dalam suasana bias gender. Pemikiran Lely ini berdasarkan cerita hidup Lely yang selalu mendapat perlakuan tidak adil dari keluarganya. Keluarganya selalu meminggirkan kehadiran kaum perempuan tanpa sebab yang jelas.

f. Intuisi

Intuisi adalah pandangan batiniah yang serta merta tembus mengeani suatu peristiwa atau kebenaran. Berdasarkan penjelasan di atas intuisi terdapat dalam kutipan berikut ini.

Anggraini muntap. Tiba-tiba, dia menyela dengan ketus, "Kalau aku tidak akan tahan! Aku sudah usir baik itu bapak maupun anaknya."

(Ibrahim, 2011: 209).

Kutipan di atas menandakan adanya gejala kognitif yang berhubungan dengan intuisi. Hal ini terlihat dari Anggraini yang tiba-tiba saja menyela omongan Lely. Tanpa berpikir panjang ia mengeluarkan omongan, tentang sikapnya seandainya ia menjadi Lely.

\section{Gejala Afektif}

Gejala afektif merupakan bagian dari kegiatan psikis yang berkenaan dengan perasaan dan emosi manusia. Banyak aspek yang menyempurnakan gejala ini.

a. Perasaan

Perasaan didefinisikan sebagai gejala psikis yang bersifat subjektif, berhubungan dengan gejala mengenal, dialami dalam kualitan senang atau tidak senang dalam berbagai taraf. Berdasarkan penjelasan di atas perasaan terdapat pada kutipan berikut ini.

"Perasaan kembali terjadi di sebuah plaza di Jakarta tahun 2002. Waktu itu, Anggraini sedang jenuh karena disertasinya masih harus diperbaiki lagi. Ia pun memutuskan untuk jalan-jalan. (Ibrahim, 2011: 15)

Kutipan di atas menandakan adanya gejala afektif yang berhubungan dengan perasaan. Hal ini terlihat dari Anggraini yang merasa jenuh karena disertasinya yang belum juga rampung. Untuk menghilangkan rasa jenuh itu Anggraini memutuskan untuk jalan-jalan.

b. Affek dan Stemming

Sumanto (dalam Emzir dan Saifur Rohman, 2015: 174) mendefinisikan Affek sebagai gejala psikis yang dapat diartikan ketegangan hebat yang timbul dalam waktu singkat tanpa disadari dengan gejalagejala jasmaniah yang luar biasa pula. Berdasarkan penjelasan di atas affek dan stemming terdapat dalam kutipan berikut ini.

Tapi, seperti kata Rahman, kalau ingin tahu dunia orang lain, maka kita harus jadi pendengar yang baik. Dengan berat hati, ia menutup rapat mulutnya. (Ibrahim, 2011: 52).

Kutipan di atas menandakan adanya gejala afektif yang berhubungan dengan affek dan steming. Hal ini terlihat dari Anggraini yang memilih menutup rapat mulutnya. Padahal rasa ingin tahunya terhadap kehidupan Lely sudah sangat besar. 
c. Suasana Hati

Suasana hati adalah kondisi perasaan yang berkesinambungan, dicirikan dengan timbulnya selalu perasaan-perasaan senang atau tidak senang yang difus (difus: tidak jelas, baur, meyebar kemanamana) sifatnya. Berdasarkan penjelasan di atas suasana hati terdapat dalam kutipan berikut ini.

\section{Sapaan perempuan itu mengagetkan Anggraini. Anggraini selalu merasa bersyukur kalau ada orang yang memanggilnya "Jeng”. Entahla, dia tidak pernah suka orang melihatnya sebagai perempuan keturunan Tionghoa (Ibrahim, 2011: 39)}

Kutipan di atas menandakan adanya gejala afektif yang berhubungan dengan suasana hati. Hal ini terlihat dari Anggraini yang merasa senang jika ada yang memanggilnya dengan "Jeng". Sebaliknya dia tidak akan senang jika ada orang yang menganggapnya perempuan Tionghoa.

d. Simpati dan Empati

Menurut Sumanto (Emzir dan Saifur Rohman, 2015: 177) Simpati adalah kecenderungan untuk ikut serta merasakan apa yang dirasakn orang lain. Adapun empati adalah suatu kecenderungan untuk merasakan sesuatu yang dilakukan orang lain andai kata dia didalam situasi orang lain tersebut. Berdasarkan penjelasan di atas simpati dan empati terdapat dalam kutipan berikut ini.

"Kalau kau merasa disakiti oleh Gunaldi, apakah tidak sebaiknya pisah saja? Tapi, ini cuma sekedar saran. Seandainya suamiku melakukan hal yang seperti Gunaldi lakukan, pasti aku sudah lama minta cerai. Menurut pendapatku cinta itu tidak bisa dibagi." (Ibrahim, 2011: 203).

Kutipan di atas menandakan adanya gejala afektif yang berhubungan dengan simpati dan empati. Hal ini terlihat dari Anggraini yang merasa kasihan terhadap Lely. Ia sampai menyuruh Lely dan Gunaldi untuk berpisah. Anggraini tidak ingin Lely terus merasa tersakiti.

\section{Gejala Konatif}

Gejala konatif adalah gejala dalam kejiwaan manusia yang berhubungan dengan usaha aktif untuk mencapai tujuan yang diinginkan.

a. Dorongan

Dorongan Menurut Kartono (Emzir dan Saifur Rohman, 2015: 177) Dorongan merupakan sesuatu kekuatan dari dalam yang mempunyai tujuan tertentu dan berlansung diluar kesadaran kita. Dorongan sendiri dibagi menjadi tiga bagian, antara lain:

1) Dorongan pada Tingkat Biologis

a) Otomatisme

Otomatisme merupakan dorongan hidup yang bekerja sehingga menimbulkan gerakan-gerakan yang terselenggara dengan sendirinya. Berdasarkan penjelasan diatas otomatisme terdapat dalam kutipan berikut ini.

Tentu saja aku merasa sedih sampai tidak bisa menceritakan kepada siapa pun tentang hal ini (Ibrahim, 2011: 42).

Kutipan di atas menandakan adanya gejala konatif yang berhubungan dengan otomatisme. Hal ini terlihat dari Lely jalan kaki ketika pulang sekolah. Karena ia tidak pernah dijemput.

b) Refleks

Refleks adalah gerak reaksi yang muncul tanpa disadari perangsang. Berdasarkan penjelasan di atas refleks terdapat dalam kutipan berikut ini.

Lely menggelengkan kepala kuat-kuat. “Aku tidak tahu siapa pemiliknya. (Ibrahim, 2011: 49).

Kutipan di atas menandakan adanya gejala konatif yang berhubungan dengan refleks. Hal ini terlihat ketika Lely menggelengkan kepalanya kuat-kuat yang menandakan ia tidak tahu ketika Anggraini bertanya. Ia tidak tahu siapa pemilik toko Papanya sekarang.

c) Insting

Insting merupakan kemampuan berbuat tertentu yang dibawa sejak lahir dan tertuju pada pemuasan dorongan-dorongan karena insting merupakan dorongan alami untuk berbuat sesuatu demi tujuan 
tertentu, dengan berlangsung secara mekanis dan tidak disadari. Berdasarkan penjelasan di atas insting terdapat dalam kutipan berikut ini.

Selepas membersihkan badan, Anggraini melihat waktu sudah menunjukkan pukul 10 malam. Anggraini menguap keras-keras. Beberapa lembar tulisan telah tertumpuk di meja. Ia masih sempat menyeruput sisa kopi susu sebelum akhirnya memutuskan untuk beristirahat (Ibrahim, 2011: 192).

Kutipan di atas menandakan adanya gejala konatif yang berhubungan dengan insting. Hal ini terlihat dari kondisi tubuh Anggraini yang sudah menuntut untuk beristirahat. Ia sudah menguap keras-keras, namun ia masih sempat menyeruput sisa kopi susunya.

d) Kebiasaan

Kebiasaan adalah bentuk tingkah laku yang tetap dari usaha adaptasi terhadap lingkungan yang mengandung unsur afektif atau perasaan. Berdasarkan penjelasan di atas kebiasaan terdapat dalam kutipan berikut ini.

Menurut analisisnya, Lely tidak akan pernah berhenti mencintai suaminya, Gunaldi, seperti kita yang tidak akan berhenti untuk melakukan hal-hal yang menjadi keseharian kita. Misalnya, mandi dua kali sehari serta makan tiga kali sehari. (Ibrahim, 2011: 192).

Kutipan di atas menandakan adanya gejala konatif yang berhubungan dengan kebiasaan. Hal ini terlihat dari menurut analisis Anggraini tidak akan pernah berhenti mencintai suaminya, seperti kita yang tidak akan berhenti melakukan kebiasaan sehari-hari kita seperti makan dan mandi.

e) Nafsu

Nafsu merupakan dorongan yang terdapat pada tiap-tiap manusia dan memberi kekuatan bertindak untuk memenuhi kebutuhan hidup tertentu. Berdasarkan penjelasan di atas nafsu terdapat dalam kutipan berikut ini.

"Pulang dari sekolah, biasanya aku langsung main di rumah Engku. Yang aku sukai di tempat Engku, aku bisa berlarian kesana-kemari. Hal itu pasti tidak akan aku lakukan di rumah. Karena kau suka berlari, Mama sering memanggilku jarang wedok (Ibrahim, 2011: 42)."

Kutipan di atas menandakan adanya gejala konatif yang berhubungan dengan nafsu. Hal ini terlihat dari keinginan Lely untuk bebas bermain. Dikarenakan kebebasan untuk bermain tidak pernah didapatkannya di rumahnya sendiri. Ia hanya akan bebas bermain ketika berada di rumah Engkunya.

f) Keinginan

Keinginan adalah nafsu yang telah berarah dan mempunyai tujuan tertentu. Berdasarkan penjelasan di atas keinginan terdapat dalam kutipan berikut ini.

“ya, aku memang ingin sekali jeda dalam kehidupan ini. (Ibrahim, 2011: 29).

Kutipan di atas menandakan adanya gejala konatif yang berhubungan dengan keinginan. Hal ini terlihat dari Anggraini ingin sekali istirahat dari rutinitasnya selama bertahun-tahun. Anggraini sudah merasakan jenuh karena mengajar ditempat yang sama serta disertasinya yang belum selesai.

g) Hasrat

Hasrat merupakan keinginan tertentu yang dapat di ulang-ulang. Berdasarkan penjelasan di atas hasrat terdapat dalam kutipan berikut ini.

Anggraini ingin bertanya banyak sekali, tapi rasanya memang tidak etis mencampuri urusan rahman dalam hal pekerjaan. (Ibrahim, 2011: 197).

Kutipan di atas menandakan adanya gejala konatif yang berhubungan dengan hasrat. Hal ini terlihat dari Anggraini yang terus ingin bertanya dengan Rahman tentang masalah yang dihadapi Lely. Namun, hal ini tidak dilakukannya karena dia tahu Rahman tidak suka kalau pekerjaannya dicampuri.

h) Kecendrungan

Kecendrungan adalah keinginan-keinginan yang kerap muncul sehingga dapat menimbulkan dasar kegemaran terhadap sesuatu. Berdasarkan penjelasan di atas kecendrungan terdaoat dalam kutipan berikut ini.

Dia berani bersumpah tidak pernah tidur dengan Tommy. (Ibrahim, 2011: 192).

Kutipan di atas menandakan adanya gejala konatif yang berhubungan dengan kecendrungan. Hal ini terlihat dari Anggraini yang berusaha jujur menceritakan bagaimana hubungannya dengn Tommy. Ia berani bersumpah jika ia dan Tommy tidak pernah tidur berdua. 
2) Dorongan pada tingkat psikologis

a) Kemauan

Kemauan adalah dorongan dari dalam yang sadar, berdasarkan pertimbangan pikir dan perasaan, serta seluruh pribadi seseorang yang menimbulkan kegiatan yang terarah pada tercapai tujuan tertentu yang berhubungan dengan kebutuhan hidup pribadinya. Berdasarkan penjelasan di atas kemauan terdapat dalam kutipan berikut ini.

Mungkin anak-anak tidak pernah tahu kalau dia masih terus ingin belajar dengan mengambil program S-3 itu agar anak-anak tahu, kendatipun Anggraini sudah tidak muda lagi, tapi tetap ingin belajar dan memberikan yang terbaik kepada mereka dan orang lain (Ibrahim, 2011: 92).

Kutipan di atas menandakan adanya gejala konatif yang berhubungan dengan kemauan. Hal ini terlihat dari Anggraini yang selalu ingin menuntut ilmu walaupun sudah tidak muda lagi. Ia meneruskan pendidikannya dengan melanjutkan program S-3.

\section{Rencana Pembelajaran Aktivitas Psikis Tokoh dalam Novel Pecinan Karya Ratna Indraswari Ibrahim}

a. Ditinjau dari Aspek Kurikulum

Penelitian tentang sktivitas psikis tokoh utama dengan pembelajaran sastra Indonesia terdapat dalam Kurikulum Tingkat Satuan Pendidikan (KTSP) pada SMA kelas sebelas (XI) semester 1 dengan Standar Kompetensi (SK) Membaca : 7. Memahami berbagai hikayat, novel Indonesia/novel terjemahan. Kompetensi Dasar (KD) 7.2. Menganalisis unsur-unsur intrinsik dan ekstrinsik novel Indonesia/terjemahan. Indikator dalam pembelajaran yaitu : 1) Mengidentifikasi unsur intrinsik (tema, tokoh, penokohan, dan amanat dalam novel Indonesia). 2) Menganalisis unsur intrinsik (tema, tokoh, penokohan, dan amanat dalam novel Indonesia).

\section{b. Aspek Tujuan Pembelajaran Sastra}

Tujuan yang ingin dicapai dalam pembelajaran sastra adalah pertama siswa memahami unsur intrinsik dan ekstrinsik dalam novel Indonesia/terjemahan. Kedua, siswa dapat mengidentifikasi unsur ekstrinsik dan intrinsik novel Indonesia/terjemahan. Ketiga, yaitu siswa dapat menganalisis unsur ekstrinsik dan intrinsik dalam novel Indonesia.

\section{c. Keterbacaan Teks}

Peneliti memilih bahan ajar pada tingkat SMA/MA sesuai dengan tujuan pembelajaran sastra yang telah peneliti paparkan sebelumnya. Pemilihan bahan ajar untuk tingkat SMA/MA yang peneliti pilih adalah aspek membaca yang berarti menganalisis unsur-unsur intrinsik dalam novel Indonesia/terjemahan. Pada pemilihan bahan ajar peneliti menjelaskan unsur-unsur intrinsik, kemudian penulis mencantumkan kutipan novel Indonesia yang berujudl Pecinan karya Ratna Indraswari Ibrahim.

\section{d. Metode Pembelajaran Sastra}

Penelitian yang dilakukan dengan pembelajaran terdapat pada kurikulum KTSP pelajaran Bahasa Indonesia yang diajarkan pada siswa SMA kelas sebelas (XI) semester 1 berkaitan dengan Standar Kompetensi membaca : 7. Memahami berbagai hikayat, novel Indonesia/terjemahan. Kompetensi Dasar 7.2. Menganalisis unsur intrinsik dan ektrinsik novel Indonesia/terjemahan. Indikator dalam pembelajaran yaitu: 1) Menganalisis unsur intrinsik (tema, tokoh, penokohan, dan amanat dalam novel Indonesia) dengan ini, penulis dapat menggunakan metode Student Teams Achievement Division (STAD) di dalam pembelajaran sastra.

Metode pembelajaran sastra dengan metode ini, peneliti merasa metode ini teapat digunakan dalam pembelajaran. Dalam metode ini peserta didik diharapkan dapat saling mendukung dan membantu satu sama lain dalam menguasai materi yang diajarkan guru. Kelebihan metode ini dapat meningkatkan kerjasama peserta didik dalam memecahkan masalah yang diberikan oleh guru. Adapun langkahlangkah dari metode Student Teams Achievement Division (STAD) adalah sebagai berikut. a) Persiapan; b) Pembagian Kelompok; c) Presentasi Guru; d) Kegiatan Kelompok; e) Kuis (Evaluasi); f) Pemberian Penghargaan. 


\section{e. Media Pembelajaran Sastra}

Peneliti menggunakan media audio visual di dalam pembelajaran sastra. Media audio visual sesuai dengan bahan ajar yang digunakan dengan Kompetensi Dasar 7.2 Menganalisis unsur-unsur intrinsik dan ekstrinsik novel Indonesia/terjemahan. Dengan menggunakan media audio visual, sesuai dengan kompetensi dasar di atas, penulis atau guru Bahasa Indonesia dan Sastra Indonesia dapat menyajikan pesan atau informasi kepada peserta didik bisa melihat dan mendengar secara langsung dengan menampilkan sebuah video kepada peserta didik dan dapat memberikan gambaran awal untuk mencari dan menemukan sebuah pemahaman yang belum mereka ketahui sebelumnya.

\section{CONCLUSION AND SUGGESTION}

Berdasarkan analisis data dengan pendekatan sosiologi sastra yang dilakukan terhadap novel Negeri di Ujung Tanduk maka peneliti dapat menarik kesimpulan mengenai Stratifikasi Sosial dalam novel Negeri di Ujung Tanduk adalah Kelas sosial berhubungan dengan kedudukannya di dalam suatu lapisan, sedangkan kedudukan mereka itu diketahui serta diakui oleh masyarakat umum. Dari penelitian ini, peneliti menemukan 11 kutipan. Status sosial meliputi suatu kedudukan sosial seseorang di masyarakat yang dapat diperoleh dengan sendirinya melalui usaha ataupun kerena pemberian. Dari penelitian ini, peneliti menemukan 11 kutipan. Kekuasaan dapat diartikan sebagai kemampuan untuk memengaruhi pihak lain menurut kehendak yang ada pada pemegang kekuasaan tersebut. Dari penelitian ini, peneliti menemukan 10 kutipan yang berhubungan dengan kekuasaan. Berdasarkan kurikulum (KTSP) terdapat empat aspek keterampilan berbahasa yang sangat penting, yaitu keterampilan menyimak, berbicara, membaca, dan menulis. Adapun yang akan dibahas dalam penelitian ini yaitu keterampilan mendengarkan. Pada kelas /semester: XII/1 dengan standar kompetensi mendengarkan 5.Memahami pembacaan novel. Kompetensi dasar 5.2.menjelaskan unsur intrinsik dari penggalan novel Indikator dalam pembelajaran yaitu menjelaskan unsur intrinsik dalam penggalan novel, dengan menggunakan metode Jigsaw dalam pembelajaran Bahasa di Sekolah. Saran yang dapat disampaikan peneliti berdasarkan hasil penelitian ini adalah Kepada pembaca diharapkan memahami makna tentang kelas sosial yang terkandung sehingga dapat memanfaatkan kelas sosial yang terdapat dalam karya sastra khususnya pada novel Negri di Ujung Tanduk karya Tere Liye. Dalam menyikapi permasalahan yang dihadapi dan dapat dijadikan pedoman dalam menentukan pergaulan di kehidupan masyarakat. Bagi pengajar khususnya pengajar Bahasa dan Sastra Indonesia dapat menjadikan kelas sosial kepada peserta didik sehingga peserta didik dapat menjadi lebih baik lagi dalam bermasyarakat. Selanjutnya dalam proses pembelajaran, pengajar harus dapat menciptakan suasana yang berinovatif yaitu dengan memilih metode dan media yang tepat dan menarik untuk menumbuhkan minat peserta didik dalam pembelajaran sastra.

\section{REFERENCES}

Emzir dan Saifur Rohman.2015. Teori dan Pengajaran Sastra. Jakarta: PT. Rajagrafindo Persada.

Ibrahim, Ratna Indraswari. 2011. Pecinan. Yogyakarta: Laksana.

Moleong, Lexy J. 2013. Metodologi Penelitian Kualitatif. Bandung: PT. Remaja Rosdakarya.

Ratna Nyoman Kutha.2004. Teori, Metode, dan Teknik Penelitian Sastra. Yogyakarta: Pustaka Pelajar. 